\title{
Catholicism and the Natural Law: A Response to Four Misunderstandings
}

\author{
Francis J. Beckwith
}

check for

updates

Citation: Beckwith, Francis J.. 2021. Catholicism and the Natural Law: A Response to Four Misunderstandings. Religions 12: 379. https://doi.org/ $10.3390 /$ rel12060379

Academic Editors: J. Caleb Clanton and Kraig Martin

Received: 27 April 2021

Accepted: 19 May 2021

Published: 24 May 2021

Publisher's Note: MDPI stays neutral with regard to jurisdictional claims in published maps and institutional affiliations.

Copyright: (C) 2021 by the author. Licensee MDPI, Basel, Switzerland. This article is an open access article distributed under the terms and conditions of the Creative Commons Attribution (CC BY) license (https:/ / creativecommons.org/licenses/by/ $4.0 /)$.
Department of Philosophy, Baylor University, Waco, TX 76710,USA; francis_beckwith@baylor.edu

\begin{abstract}
This article responds to four criticisms of the Catholic view of natural law: (1) it commits the naturalistic fallacy, (2) it makes divine revelation unnecessary, (3) it implausibly claims to establish a shared universal set of moral beliefs, and (4) it disregards the noetic effects of sin. Relying largely on the Church's most important theologian on the natural law, St. Thomas Aquinas, the author argues that each criticism rests on a misunderstanding of the Catholic view. To accomplish this end, the author first introduces the reader to the natural law by way of an illustration he calls the "the ten (bogus) rules." He then presents Aquinas' primary precepts of the natural law and shows how our rejection of the ten bogus rules ultimately relies on these precepts (and inferences from them). In the second half of the article, he responds directly to each of the four criticisms.
\end{abstract}

Keywords: Catholicism; natural law theory; Aquinas; naturalistic fallacy

The purpose of this article is to respond to several misunderstandings of the Catholic view of the natural law. I begin with a brief account of the natural law, relying primarily on the work of St. Thomas Aquinas, the Church's most important theologian on this subject. I then move on and offer replies to four criticisms of the natural law that I argue rest on misunderstandings: (1) the natural law commits the so-called "naturalistic fallacy," (2) the natural law makes Scripture superfluous, (3) the natural law mistakenly claims that there is a universally shared body of moral beliefs, and (4) the natural law ignores the noetic effects of sin. My replies are not intended to be exhaustive, but merely suggestive of how a Catholic natural law advocate can respond to these criticisms. Moreover, I do not explore the differing schools of thought embraced by those who identify as natural law theorists. However, attentive readers will quickly recognize the view I am presenting as aligning most closely with what is sometimes called the "old natural law," a view whose advocates defend the idea that, for natural law to work, it requires something like an Aristotelean-Thomistic metaphysics.

\section{The Natural Law}

According to the Catechism of the Catholic Church $(2000,1956)$, "The natural law, present in the heart of each man and established by reason, is universal in its precepts and its authority extends to all men. It expresses the dignity of the person and determines the basis for his fundamental rights and duties." This means that morality is real, that it is natural and not a mere human artifice or construction, that all human beings can know it when we exercise our reason, and that it is the measure by which we judge how we should treat others as well as ourselves. This is the moral law to which Martin Luther King, Jr. was referring in his famous Letter from Birmingham Jail (King 1963): "A just law is a man-made code that squares with the moral law or the law of God. An unjust law is a code that is out of harmony with the moral law." For King, we can assess the goodness or badness of ordinary human law-whether criminal or civil—by testing it against a natural moral law that we did not invent. Although this way of conceptualizing our understanding of law is rarely verbalized in common conversation, our moral reflexes almost always indicate that 
we presuppose it. Think, for example, of how you would react if any one of the following rules were embedded in the laws of your own government: ${ }^{1}$

1. Parents may abandon their minor children without any justification and without any requirement to provide financial support.

2. It is permissible for a city or state to pass post facto laws.

3. The maximum punishment for first-degree murder is an all-expense paid vacation to Las Vegas.

4. Any city or state may pass secret laws that the public cannot know.

5. Anyone may be convicted of a crime based on the results of a coin toss.

6. All citizens are forbidden from believing, propagating, or publicly defending the view that there is a moral law against which nations and individuals are measured.

7. Your guilt or innocence in a criminal trial depends entirely on your race and not on a judge or jury's deliberation on legitimately obtained evidence.

8. Government contracts are to be distributed based on family connections and bribes and not on the quality of the bids.

9. Original parenthood is to be decided by a special board of experts appointed by the governor and not on whether one sires or begets the child.

10. No citizen may believe, propagate, or publicly defend the view that there is a transcendent source of being that has underived existence.

When you reject these ten (bogus) rules (as you should), you do so on the basis of something you already know. You reject rules 1 and 9 because you know that parents have a natural obligation to care for their offspring and that original parenthood is determined by siring and begetting. This is why adoptive parenthood without the explicit permission of the child's natural parents is just a species of kidnapping. ${ }^{2}$ You reject rules 2 and 5 because you know that law should be based on reason. It is unreasonable to prosecute someone for a crime that was not a crime when she committed it, and it is unjust for a court to determine a verdict by an arbitrary and capricious method. Along similar lines, you reject rules 4 and 7. An unknowable law is like a post facto law, and one's race is as relevant to one's criminal guilt or innocence as is a coin flip. You reject 8 because you know that it is unjust for a government to award someone a contract based on their genealogy and willingness to bribe, for neither has any bearing on whether one deserves the contract. You reject rule 3 because you know that human life is sacred and that a just society must reflect that in its laws. To reward someone for intentionally killing the innocent is an abomination. Because you know that the human mind has a natural inclination to know not only particular and mundane truths, but universal and transcendent truths as well, you reject rule 10. For rule 10 essentially prohibits the full exercise of a power that is distinctly human, what Aquinas called "speculative reason." ${ }^{3}$ And finally, you reject rule 6 because you know that societies and individuals can be properly judged by a moral law external to their own practices and beliefs. You know on a personal level that you sometimes fall short of the moral law's requirements. ${ }^{4}$ Like all of us, you make excuses, rationalize, or ignore your own moral indiscretions, though on occasion you are moved by conscience to confess your wrongdoing. But what is true of individuals is also true of civilizations, for it seems perfectly permissible for one to issue judgments about the conduct of nations that have perpetuated atrocities and injustices, even when those nations' apologists rattle off a litany of excuses and rationalizations or feign ignorance.

According to the Catholic Church, your rejection of the ten bogus rules is the result of your acquaintance with the natural law, even if you are not conspicuously aware of it. This is possible because human beings are ordered toward certain goods, and as rational animals, we have the capacity to recognize and make judgments about those goods and realize that we ought to choose them. As Aquinas notes, "Since ... good has the nature of an end, and evil, the nature of a contrary, hence it is that all those things to which man has a natural inclination, are naturally apprehended by reason as being good, and consequently as objects of pursuit, and their contraries as evil, and objects of avoidance." (Thomas Aquinas 1920, I.II, Q94, art. 2, respondeo). What Aquinas is saying here is that we are, in 
a sense, hardwired to acquire knowledge of the precepts of the natural moral law, just as we are hardwired to learn mathematics and speak a language and discover rules about them. ${ }^{5}$ To understand what Aquinas means, we will review his brief account of what are sometimes called the primary precepts of the natural law. It is from these primary precepts, Aquinas argues, that we can derive other precepts, which he calls the secondary precepts of the natural law (Thomas Aquinas 1920, I.II, Q94, art. 5, 6).

(1) "[G]ood is to be done and pursued, and evil is to be avoided." (Thomas Aquinas 1920, I.II, Q94, art. 2, respondeo). Calling this the first precept of the natural law, Aquinas grounds it in the common-sense observation that every human being knows at some level that she ought to seek after what she believes is good for her, even if it is not really good for her. The alcoholic, for example, pursues the bottle because he desires the good of being at rest, to attain some sense of internal peace and contentment. When he conquers his addiction and changes his ways, he does so because he more fully understands how best to fulfill this first precept. He realizes that by his excessive drinking he had unwittingly been violating the precept, that he in fact was not really doing good or avoiding evil. Although you reject each of the ten bogus rules for specific reasons, e.g., the precept that one ought not to intentionally kill the innocent, your duty to act in accordance with those reasons depends on this more general precept: good should be done and evil avoided.

(2) "[W]hatever is a means of preserving human life, and of warding off its obstacles, belongs to the natural law." (Thomas Aquinas 1920, I.II, Q94, art. 2, respondeo). Like all living things, human beings have an inclination to continue in existence. But unlike those other living things - which are directed by mere instinct or learned behavior, and not by intellect and will-human beings can apprehend the sort of existence appropriate to the kind of being we are. So, when Aquinas talks about "preserving human life", he does not mean mere biological existence. We do, of course, apprehend the evil of killing, since we apprehend what is good for us. But we also know that the preservation of human life consists in far more than mere survival, but must include the sorts of relationships, institutions, and communal goods that make life worth living and allow us to flourish consistent with the ends of our nature. ${ }^{6}$

Although we rightly conclude from this precept that we ought to avoid death and not kill, we also come to recognize, by the exercise of our reason, that preserving the life appropriate to our species entails that killing may sometimes be justified and death should not be avoided at all costs. Thus, we come to believe that there are cases of permissible killing, e.g., just war, self-defense, as well as cases in which not avoiding death is not a violation of the natural law, e.g., martyrdom, certain supererogatory acts. ${ }^{7}$ The justification of those apparent exceptions is the result of a further elaboration of the natural law. Take, for example, self-defense. Because I have an inclination to preserve my life, I have a right to protect it, which means that there may be occasions in which my exercise of that right results in the death of the assailant trying to unjustly take my life. As we shall see in the fourth primary precept, because we are rational and social beings that are ordered toward the shunning of ignorance, knowing the truth about God, and living with others in peace, we can infer from the natural law's primary precepts more precise precepts about the extent to which we are permitted to kill ("You may kill in self-defense so that your life may not be unjustly taken by someone who does not want to live at peace with others") or not avoid death ("Your duty to God, which is your highest duty, may require that you die for your faith if denying it is the only way to avoid death.") Hence, your rejection of bogus rule 3 is based on a secondary precept of the natural law: one should not intentionally kill the innocent.

(3) "[T]here is in man an inclination to things that pertain to him more specially, according to that nature which he has in common with other animals: and in virtue of this inclination, those things are said to belong to the natural law, 'which nature has taught to all animals' ..., such as sexual intercourse, education of offspring and so forth." (Thomas Aquinas 1920, I.II, Q94, art. 2, respondeo). Here, Aquinas is telling us that our sexual powers are ordered toward reproduction and that we have a solemn responsibility to our offspring 
that are brought into being from the exercise of those powers. Like all animals, we have a natural inclination to reproduce and care for our young. But unlike other animals, we possess intellect and will, which means that we can choose to resist our natural inclinations while still apprehending why it is sometimes evil to do so. For this reason, we infer from this primary precept of the natural law that child abandonment and state denial of parental rights are both prima facie evil. As should be obvious, your knowledge of this secondary precept of the natural law is the reason why you reject bogus rules 1 and 9.

(4) "[T]here is in man an inclination to good, according to the nature of his reason, which nature is proper to him: thus man has a natural inclination to know the truth about God, and to live in society: and in this respect, whatever pertains to this inclination belongs to the natural law; for instance, to shun ignorance, to avoid offending those among whom one has to live, and other such things regarding the above inclination." (Thomas Aquinas 1920, I.II, Q94, art. 2, respondeo). Here, Aquinas is saying that we have an inclination to reason well and eschew ignorance (because we are beings with intellect), live peaceably with others (because we are socially dependent beings), and know the highest truth (because we are beings with intellect that may exercise speculative reason). That is, we are naturally ordered toward these ends and to intentionally act contrary to them is to engage in evil. It is clear from your rejection of bogus rules 2, 4, 5, 6, 7, 8, and 10 that you already know this. Bogus rules 2 and 4 intentionally make citizens ignorant of the law, bogus rules 5, 7, and 8 enshrine irrationality in the law, and bogus rules 6 and 10 prohibit citizens from pursuing and expressing the highest truths about morality and God. ${ }^{8}$ Also, all the bogus rules in one way or another make it extraordinarily difficult to avoid "offending those among whom one has to live."

For Aquinas and the Catholic Church, natural law is not the only kind of law. There is eternal law, divine law, and human law, all of which are essential to understanding the natural law. Eternal law is the order of the universe in the mind of God. Divine law is Sacred Scripture. And human law is the civil law and law of nations instituted by human governments. I will have more to say about each in Section 2, since some of the misunderstandings to which I will respond are often the result of natural law's critics ignoring one or more of these other types of law.

\section{Four Misunderstandings}

In this section, I am going to assess four misunderstandings of the natural law. I intend nothing more than to offer corrections to how some critics of the natural law conceptualize it. Thus, my comments are not meant as a defense of the truth of the natural law (though I believe it is true) but, rather, as a clarification of what the Catholic Church (and Aquinas) actually believes about the natural law. Because the second, third, and fourth misunderstandings are clustered together in a famous article by the Evangelical theologian, Carl F. H. Henry (1995), I address them together under one heading.

\subsection{The Natural Law Commits the So-Called "Naturalistic Fallacy"}

Some critics of the natural law argue that it commits what is sometimes called the "naturalistic fallacy," that its advocates mistakenly try to derive an "ought" from an "is," a normative conclusion from a factual premise. So, for example, it would be fallacious for one to argue from the fact that peyote is a naturally growing substance to the conclusion that one ought to consume peyote. In the same way, points out the critic, the natural law theorist fallaciously argues from the facts of human inclinations to the conclusion that one ought not to intentionally act contrary to them.

Although it is certainly true that it is sometimes fallacious to attempt to derive a normative conclusion from a factual premise-e.g., pot smoking is legal therefore you ought to smoke pot-this is not always the case. For one thing, the "facts" with which the natural law theorist is working are embedded in a teleological worldview, one in which all living creatures have natures that tell us what is good for them as well as inclinations that move these creatures to those good ends. The sapling in your back yard, for example, is 
ordered toward becoming an oak tree and thus it has inclinations to perform photosynthesis and absorb minerals from the soil for that end. Because we know the sapling's nature, we know that its becoming an oak tree is a perfection of its nature and thus good for it do so. But, as I have already noted, human beings are not like other creatures, for we have intellect and will and are thus able to make real choices that may be contrary to or consistent with the good to which our inclinations are ordered. So, for example, if one is purposely ignorant, abandons one's children, or intentionally kills an innocent bystander, then one has made an immoral choice contrary to the goods to which one is ordered, which includes the acquisition of knowledge, the caring for one's offspring, the preserving of human life, and living at peace with others.

To be sure, some philosophers reject natural teleology altogether, along with the Aristotelean-Thomistic metaphysics on which its advocates typically rely, while others, the so-called "new natural law theorists," believe that the truth of natural law does not depend on natural teleology (see Lee 2019; Crowe 2017). But given the modesty of our task-to merely offer conceptual clarification on how the Catholic Church, and how Aquinas (as conventionally interpreted), ${ }^{9}$ understands the natural law ${ }^{10}$ - there is no need to wade into those extra- and intramural disputes in this venue.

Second, outside of explicit discussions of natural law, we often make legitimate judgments that seem to rely on natural facts that imply good ends that one ought to pursue. Consider first the comments made by Richard Dawkins about Kurt Wise, a Harvard-trained paleontologist. Wise was brought up in a Fundamentalist Christian home in which he was taught that the Bible teaches that the Earth is no more than 10,000 years old. Not only did Wise not abandon this belief after earning his Harvard $\mathrm{PhD}$, but he came to the conclusion that if he were to do so, he would be abandoning his faith in Scripture, the Word of God. ${ }^{11}$ So, by sticking with his young earth views, Wise recognized that he had given up any chance of landing a professorship at a major research university. In an autobiographical essay quoted by Dawkins, Wise laments: "With that, in great sorrow, I tossed into the fire all my dreams and hopes in science." (Ashton 2000; quoted in Dawkins 2006, p. 285). In his assessment of Wise's decision, Dawkins writes:

As a scientist, I am hostile to fundamentalist religion because it actively debauches the scientific enterprise. It teaches us not to change our minds, and not to want to know exciting things that are available to be known. It subverts science and saps the intellect. The saddest example I know is that of the American geologist Kurt Wise ... The wound, to his career and his life's happiness, was self-inflicted, so unnecessary, so easy to escape. All he had to do was toss out the bible. Or interpret it symbolically, or allegorically, as the theologians do. Instead, he did the fundamentalist thing and tossed out science, evidence and reason, along with all his dreams and hopes. (Dawkins 2006, pp. 284, 285)

Note the teleological reasoning undergirding Dawkins' assessment of Wise. He is saying that Wise-an intelligent, gifted, and well-credentialed scientist—ought to have used his talents in a way that would have led to his happiness, and that his fundamentalist beliefs were an impediment to that end. Because of the sort of being Wise is-a being with intellect and will whose end is happiness-he has an obligation to make choices consistent with that end. Aquinas, unsurprisingly, concurs: " $[\mathrm{M}] \mathrm{an}$ 's last end is happiness; which all men desire, as Augustine says (De Trin. xiii, 3,4)" (Thomas Aquinas 1920, I.II Q1.art8, sed contra). ${ }^{12}$

Now consider the fanciful case of David and his optometrist, Thomas. Suppose David is examined by Thomas, who tells him, ${ }^{13}$ "It looks like you are nearsighted and you ought to use corrective lenses." David replies: "But doc, you just made an illicit inference, for you can't get an ought from an is. Just because I am nearsighted doesn't mean that I ought to use corrective lenses. At least that's what Hume taught me."14 Thomas, having read Aquinas, responds with a series of questions to which David offers a series of replies: "Should you do good and avoid evil?" "Yes." "Is improved eyesight good for you?" "Yes." "Would corrective lenses improve your eyesight?" "Yes." "So if you should do good and avoid evil, 
and if using corrective lenses is good for you, should you use corrective lenses?" "Yes." "Sounds like a valid inference to me. Read Aquinas' On Being and Essence and call me in the morning." (Thomas Aquinas 1968).

Third, the natural law critic seems to rely on the very sort of reasoning she claims is fallacious when employed by the natural law theorist. For she is arguing that, because the natural law theorist mistakenly attempts to derive an ought from an is, you ought not to follow the natural law theorist's example. The critic seems to be assuming that our mental faculties-the powers we employ when we exercise our reason-are ordered toward a good end, knowledge, and that believing in natural law theory is counter to that end. But that is equivalent to assuming the truth taught by the fourth primary precept of the natural law: shun ignorance because your mind is ordered to the good of knowledge!

2.2. Natural Law Makes Scripture Superfluous, Mistakenly Affirms Universal Moral Beliefs, and Ignores the Noetic Effects of Sin

Christian critics of the natural law sometimes depict it as a theory that marginalizes Scripture, overrates the universality of common moral beliefs, and ignores our fallen human nature. One such critic, Carl F. H. Henry, writes:

The three contentions of the Thomist doctrine of natural law that evoke evangelical criticism are: (1) that independently of divine revelation, (2) there exists a universally shared body or system of moral beliefs, (3) that human reasoning articulates despite the noetic consequences of the Adamic fall. (Henry 1995, p. 55)

Henry is mistaken on all three points. (1) There are two senses in which the natural law is not independent of divine revelation (which Aquinas calls the divine law). First, the natural law and the divine law (the Old and New Testaments) are both derived from the same eternal law, which is the order of the created universe in the mind of God. Because God is the creator of human nature, and because knowing the natural law requires the exercise of human reason, Aquinas says that "by the natural law the eternal law is participated proportionately to the capacity of human nature" (Thomas Aquinas 1920, I.II, Q94, art. 4, a.1). In a sense, then, the natural law, because it depends on the deep structure of our nature, is a reflection of the eternal law in the mind of God. Second, the natural law is not independent of divine law insofar as the natural law is deficient for securing our supernatural end. Writes Aquinas: "[I]f man were ordained to no other end than that which is proportionate to his natural ability, there would be no need for man to have any further direction, on the part of his reason, in addition to the natural law and humanly devised law which is derived from it" (Thomas Aquinas 1920, II.I, Q91, art. 4, respondeo). Here, Aquinas mentions both natural law and human law as being inadequate for the end to which we are ordained: beatitude, eternal happiness in union with God (Human law, as noted above, refers to the civil law and the law of nations, which are derived from the natural law. They are, in a sense, applications of the natural law to the conditions of particular peoples). For this reason, we need the divine law, a special communication from God to human beings that could not be derived from human reason.

Aquinas also tells us that we need the divine law "because, on account of the uncertainty of human judgement, especially on contingent and particular matters, different people form different judgments on human acts; whence also different and contrary laws result" (Thomas Aquinas 1920, II.I, Q91, art. 4, respondeo). In other words, because the natural law by itself, without the help of the divine law, cannot quell many doubts about what a human being "ought to do and what he ought to avoid, it was necessary for man to be directed in his proper acts by a law given by God, for it is certain that such a law cannot err" (Thomas Aquinas 1920, II.I, Q91, art. 4, respondeo). As the Catechism states: "The precepts of natural law are not perceived by everyone clearly and immediately. In the present situation sinful man needs grace and revelation so moral and religious truths may be known 'by everyone with facility, with firm certainty and with no admixture of error.'" (2000, 1960, quoting from Pius XII 1950, 3). ${ }^{15}$ The natural law, for example, can tell us that the union of one man and one woman is good, but without the divine law, one 
cannot know that marriage is a sacrament or that it is indissoluble. In the same way, the natural law can tell us that there are four cardinal virtues, but it cannot tell us that there are theological virtues called faith, hope, and charity.

(2) The Church does not claim that "there exists a universally shared body or system of moral beliefs." Henry seems to be saying that the Church believes that all human beings have an infallible and complete access to the correct set of moral rules: "Natural law theory promises uniformity of truth claims and of moral conviction and behavior" (Henry 1995, p. 58). To be sure, the Church does teach that everyone knows the primary precepts of the natural law, but given differing cultural conditions in a diversity of societies and the role that human passions play in obstructing the natural law in particular cases, the Church recognizes that there is no one "universally shared body or system of moral beliefs" as Henry claims. As the Catechism $(2000,1957)$ states: "Application of the natural law varies greatly; it can demand reflection that takes account of various conditions of life according to places, times, and circumstances. Nevertheless, in the diversity of cultures, the natural law remains as a rule that binds men among themselves and imposes on them, beyond the inevitable differences, common principles."

Consider first the various forms of government as well as the wide range of civil and criminal laws throughout the world. In most cases, the differences arise as a consequence of a nation's history and traditions. Some nations, like the United States, have constitutions. Others are non-constitutional monarchies. Germany outlaws "extremist symbols," while the U.S. does not. In some societies, the death penalty is permitted. Most of the world drives on the right side of the road, while citizens of the United Kingdom (and a few others) drive on the left. In all societies, homicide, theft, rape, and insurrection are violations of the criminal law, though there are disagreements on precise definitions and degrees as well as what would constitute appropriate punishments. The point is that all legitimate human law $^{16}$ - even in its wide diversity - reflects the natural law insofar as it is an attempt to recognize and protect those goods to which we are ordered.

Consider now the contested issue of abortion. ${ }^{17}$ We often think that the differing sides in this debate hold radically different moral views. ${ }^{18}$ They most certainly do on the question of the moral permissibility of abortion, but is it disagreement all the way down? Not at all. Take, for example, one of the secondary precepts of the natural law: it is wrong to intentionally kill innocent persons. Both prolifers and prochoicers agree with this precept. Where they disagree is on the question of what constitutes an innocent person. Prolifers believe that all unborn human beings are innocent persons, whereas prochoicers don't. Some prochoicers argue that the unborn are not persons (see Warren 1973), whereas others argue that, even if they are persons, they are not technically "innocent" since those that are unwanted are unwelcome intruders on the woman's bodily integrity (see Thomson 1971; Boonin 2019). The point here is that even on an issue like abortion, one over which there is deep disagreement, each side defends its view under the assumption that a precept of the natural law is true.

(3) As should be obvious from my responses to Henry's first and second points, the Church does in fact take seriously the noetic effects of sin. Aquinas, for instance, explains that when it comes to the natural law's secondary precepts, "the natural law can be blotted out from the human heart, either by evil persuasions, just as in speculative matters errors occur in respect of necessary conclusions; or by vicious customs and corrupt habits, as among some men, theft, and even unnatural vices, as the Apostle states (Romans 1), were not esteemed sinful" (Thomas Aquinas 1920, II, Q94, art. 6, respondeo). This explains why many human beings, though having knowledge of the primary precepts of the natural law, nevertheless commit great evils. The murderer, for example, knows the good of the preservation of life, for he not only seeks to protect his own life, but often kills for the sake of his own interests, the good of his life as he understands it. He is in indeed corrupt. But we can only make that judgment if we already know the sort of human being he ought to be, i.e., if we already know the natural law. 


\section{Conclusions}

My intent in this article was not to argue for the truth of the Catholic view of the natural law (even though I believe it is true), but rather, (1) to suggest (by using the ten bogus rules) that the natural law comes more naturally to us than we may ordinarily suspect, that it may very well be, in the words of J. Budziszewski, "what we can't not know" (Budziszewski 2011), and (2) that four of the most common criticisms of the natural law rest on misunderstandings of it. This, of course, does not mean that one cannot critique the natural law on other grounds, or that one may not reasonably conclude that there are rival ethical theories that do just as well (if not better) in accounting for the common moral intuitions on which our rejection of the ten (bogus) rules seems to rest.

Funding: This research received no external funding.

Institutional Review Board Statement: Not applicable.

Informed Consent Statement: Not applicable.

Data Availability Statement: Not applicable.

Conflicts of Interest: The authors declare no conflict of interest.

\section{Notes}

1 This list is inspired by Lon Fuller's fictional story of an evil monarch named Rex (Fuller 1969, pp. 33-41).

2 An exception would be cases in which the parents of minor children die without having provided in their will directions for their children's guardianship. But even here state laws reflect the primacy of original parenthood by allowing guardianship to the closest relatives (e.g., grandparents, aunt, uncle) with the best interests of the child in mind (e.g., an abusive alcoholic grandparent may be bypassed for a close family friend or aunt).

3 "Now, there are some objects of speculation that depend on matter for their being, for they can only exist in matter. And these are subdivided. Some depend on matter both for their being and for their being understood, as do those things whose definition contains sensible matter and which, as a consequence, cannot be understood without sensible matter. For example, it is necessary to include flesh and bones in the definition of man. It is things of these sort that physics or natural science studies. On the other hand, there are some things that, although dependent upon matter for their being, do not depend on it for their being understood, because sensible matter is not included in their definitions. This is the case with lines and numbers-the kinds of objects with which mathematics deals. There are still other objects of speculative knowledge that do not depend upon matter for their being because they can exist without matter; either they never exist in matter, as in the case of God and the angels, or they exist in matter in some instances and not in others, as in the case of substance, quality, potency, act, one and many, and the like. The science that treats of all these is theology or divine science, which is so called because its principal object is God. By another name it is called metaphysics; that is to say, beyond physics, because it ought to be learned by us after physics, for we have to proceed from sensible things to those that are non-sensible. It is also called first philosophy, inasmuch as all the other sciences, receiving their principles from it, come after it ... " (Thomas Aquinas 1953, Q5.a1) (In order to make this quote more accessible, I slighted edited it from how it appears in the original).

4 C. S. Lewis put it more eloquently: "These, then, are the two points I wanted to make. First, that human beings, all over the earth, have the curious idea that they ought to behave in a certain way, and cannot really get rid of it. Secondly, that they do not in fact behave in that way." (Lewis [1952] 1997, p. 21).

5 Just as some human beings cannot learn mathematics or master a language because of immaturity or disability, some human beings never come to know the natural law for the same reasons. This is why it is wrong to say that Aquinas or the Catholic Church teaches that the natural law is innate in each and every human being.

6 This is a point made by J. Budziszewski, "[P]reservation of its being means not the preservation of its bare existence, but the preservation of the mode of life that the fulfillment of its nature requires-a mode of life that is shaped by all of its natural inclinations, not just the first inclination, but others too." (Budziszewski 2014, p. 249).

7 A supererogatory act is one that is above and beyond the call of duty, as in the case of a soldier jumping on a live grenade to save his buddies. He does not will his own death, but he knowingly sacrifices his own life to save others. (We know he is not willing his own death because he would not be disappointed if the grenade turned out to be a dud). Perhaps this is the sort of sacrifice Jesus had in mind when he said, "No one has greater love than this, to lay down one's life for one's friends." (Jn 15:13-NRSV). 
8 It is important to note here that Aquinas and the Church are not suggesting that moral relativists and atheists do not exist. What they are saying is that human beings have a natural inclination to pursue ultimate truths about morality and God. After all, the moral relativist's rejection of the natural law and the atheist's rejection of God's existence means that each has an inclination to pursue the truth of these questions, even though each arrives at answers antithetical to conclusions drawn by Aquinas and the Church. Nevertheless, the Church maintains that we are ordered toward these ends because they really do exist, and that in the case of God we cannot know him in the fullest sense until we experience him in the beatific vision in the afterlife.

9 I say "as conventionally interpreted," since the new natural law theorists believe that their interpretation of Aquinaswhich challenges the conventional interpretation-is the correct one. For more, see Lee (2019).

10 The () affirms teleology as integral to its explication of the natural law: "The moral law presupposes the rational order, established among creatures for their good and to serve their final end, by the power, wisdom, and goodness of the Creator. All law finds its first and ultimate truth in the eternal law." (1951) (emphasis added).

11 It should go without saying that Wise's literalistic interpretation of the Bible-in particular, the first chapters of Genesis-is not the only way to interpret Scripture while maintaining a high view of it. See, e.g., (Carroll 2002).

12 As I note elsewhere: "Although Aquinas believed that God, the Sovereign Good, is the object and cause of Happiness,' one need not believe in God to recognize, as Dawkins does, that human beings by nature are ordered toward happiness. Aquinas, of course, maintained that nothing short of God could suffice for Perfect Happiness, since everything that gives us imperfect happiness - pleasure, bodily goods, wealth, honor, intellectual accomplishmentsis fleeting and temporary. Nevertheless, the point here is that Dawkins, despite his best efforts, cannot rid himself of the common sense reflexes that require the reality of final causality." (Beckwith 2019, p. 82, quoting Thomas Aquinas 1920, I.II, Q5, art. 5, respondeo)

13 This dialogue is inspired by a similar one authored by Budziszewski (2014, p. 248).

14 Hume writes: "In every system of morality, which I have hitherto met with, I have always remarked, that the author proceeds for some time in the ordinary ways of reasoning, and establishes the being of a God, or makes observations concerning human affairs; when all of a sudden I am surprised to find, that instead of the usual copulations of propositions, is, and is not, I meet with no proposition that is not connected with an ought, or an ought not. This change is imperceptible; but is however, of the last consequence. For as this ought, or ought not, expresses some new relation or affirmation, 'tis necessary that it should be observed and explained; and at the same time that a reason should be given; for what seems altogether inconceivable, how this new relation can be a deduction from others, which are entirely different from it. But as authors do not commonly use this precaution, I shall presume to recommend it to the readers; and am persuaded, that this small attention would subvert all the vulgar systems of morality, and let us see, that the distinction of vice and virtue is not founded merely on the relations of objects, nor is perceived by reason." (Hume [1739] 2000, p. 302).

15 English translation of Humani Generis quote is unique to Catechsim. The Vatican's official translation of the encyclical differs slightly. It can be found online here: http:/ /www.vatican.va/content/pius-xii/en/encyclicals/documents / hf_p-xii_enc_12081950_humani-generis.html (accessed on 21 May 2021)

16 I say "legitimate human law" because Aquinas holds that some so-called human laws are unjust and thus not real laws. See (Thomas Aquinas 1920, II.I, Q96, art. 4, respondeo).

17 For two different moral perspectives on the question, Beckwith (2007) and Boonin (2002).

18 I am aware that there is a spectrum of views on abortion, that there are not just two camps, as popular media often portray it. But for the point I am trying to make here, it is not necessary that I cover all those views.

\section{References}

Ashton, John F. 2000. In Six Days: Why 50 Scientists Choose to Believe in Creation. Green Forrest: Master Books.

Beckwith, Francis J. 2007. Defending Life: A Moral and Legal Case against Abortion Choice. New York: Cambridge University Press.

Beckwith, Francis J. 2019. Never Doubt Thomas: The Catholic Aquinas as Evangelical and Protestant. Waco: Baylor University Press.

Boonin, David. 2002. A Defense of Abortion. New York: Cambridge University Press.

Boonin, David. 2019. Beyond Roe: Why Abortion Should Be Legal-Even if the Fetus is a Person. New York: Oxford University Press.

Budziszewski, J. 2011. What We Can't Not Know: A Guide, Revised and Expanded Edition. San Francisco: Ignatius Press.

Budziszewski, J. 2014. Commentary on Thomas Aquinas' Treatise on Law. New York: Cambridge University Press.

Carroll, William E. 2002. Creation, Evolution, and Thomas Aquinas. Revue des Questions Scientifiques 171: 319-47.

Crowe, Jonathan. 2017. Metaphysical Foundations of Natural Law Theories. In The Cambridge Companion to Natural Law Jurisprudence. Edited by George Duke and Robert P. George. New York: Cambridge University Press, pp. 103-29.

Catechism of the Catholic Church: Revised in Accordance with the Official Latin Text Promulgated by Pope John Paul II, 2nd ed. Washington: United States Conference of Catholic Bishops. 
Dawkins, Richard. 2006. The God Delusion. London: Bantam.

Fuller, Lon L. 1969. The Morality of Law, Revised edition. New Haven: Yale University Press.

Henry, Carl F. H. 1995. Natural Law and Nihilistic Culture. First Things 49: 55.

Hume, David. 2000. A Treatise on Human Nature. Edited by David Fate Norton and Mary J. Norton. Oxford: Clarendon Press. First published 1739 .

King, Martin Luther, Jr. 1963. Letter from a Birmingham Jail. April 16. Available online: https://www.africa.upenn.edu/Articles_Gen/ Letter_Birmingham.html (accessed on 21 May 2021).

Lee, Patrick. 2019. The New Natural Law Theory. In The Cambridge Companion to Natural Law Ethics. Edited by Tom Angier. New York: Cambridge University Press, pp. 73-91.

Lewis, Clives Staples. 1997. Mere Christianity. London: Collins. First published 1952.

Pius XII. 1950. Humani Generis. August 12. Available online: http://www.vatican.va/content/pius-xii/en/encyclicals/documents/hf_ p-xii_enc_12081950_humani-generis.html (accessed on 21 May 2021).

Aquinas, Thomas. 1920. Summa Theologica. Literally translated by Fathers of the English Dominican Province. Available online: http:/ / www.newadvent.org/summa/ (accessed on 21 May 2021).

Aquinas, Thomas. 1953. Super Boethium De Trinitate, trans. Armand Mauer. Toronto. Available online: https://isidore.co/aquinas / english/BoethiusDeTr.htm\#51 (accessed on 21 May 2021).

Aquinas, Thomas. 1968. On Being and Essence (De Ente Et Essentia). Translated by Armand Maurer. Toronto: Pontifical Institute Medieval Studies.

Thomson, Judith Jarvis. 1971. A Defense of Abortion. Philosophy E Public Affairs 1: 47-66.

Warren, Mary Anne. 1973. On the Moral and Legal Status of Abortion Rights. The Monist 57: 43-61. [CrossRef] 